\title{
Impact of Meaning in Life on Psychological Well Being among Street Children
}

\author{
J. Ashok ${ }^{1}$, Dr. P. Swati ${ }^{2}$ \\ ${ }^{1}$ Osmania University Hyderabad
}

\begin{abstract}
The present examines the impact of meaning in life on psychological well being among street children. The present study was conducted on 60 street children of Hyderabad. The findings of the study revealed that street children have low meaning of life and psychological well being. A strong direct positive relationship between meaning to life and psychological well being was found.
\end{abstract}

Keywords: meaning in life, psychological well being, street children

\section{Introduction}

Street children are minors who live and survive on the streets. They often grow up in bus stations, railway station and other public places. Because of conflicts with their family, these children don ${ }^{\text {ee }}$ or can ${ }^{\text {ect }}$ return home. These children are faced with multiple problems and as a consequence some of their rights are often compromised. The rates of regressive behavior, anxiety, and depression in street children were found much higher than their counterparts in common children (Ayerst, 1999; Donald \& Swart-Kruge, 1994). Street life significantly reduced the street children "es subjective wellbeing (SWB), which was lower than those of regular people.

Meaning in life typically involves having a goal or a sense of unified purpose (Baumeister, 1991; Ryff, 1989). Recker, Peacock and Wong (1987), defined meaning as it "refers to making sense, order, or coherence out of one "s existence and having a purpose and striving toward a goal or goals". More recently Wong (1998) defined meaning as "an individually constructed, culturally based cognitive system that influences an individual ${ }^{\text {ee }} \mathrm{s}$ choice of activities and goals, and endows life with a sense of purpose, personal worth, and fulfillment" The importance of meaning in life and commitment to personal life satisfaction and psychological health has been well established (Erikson, 1982; Ledbetter, Smith \& VoslerHunter1991; Ryff, 1989; Stephen, Fraser \& Marcia, 1992). Studies have shown that seeking meaning and fulfillment acts as a significant protector against emotional instability, and as a warrantor of psychological health and well-being (Lukas, 1991). Meaning in life has been found to be a strong and consistent predictor of psychological well-being (Zika\& Chamberlain, 1987). Shek (1992) conducted a study on Chinese secondary students and found that students who scored highest in terms of quality of existence as well as purpose of existence also scored highest in psychological well-being.

Objective: The present study was aimed at studying the impact of meaning in life on psychological well being among street children

Tools: In present study Meaning in life questionnaire by Michael F. Steger, (2005)which measures two dimensions presence and search was used. The scale of psychological well being was used to measure psychological well being. This scale has six dimensions: autonomy, environment, mastery, personal growth.

Sample: The sample for this study was selected from Hyderabad. The sample consisted of 60 street children. The sample was drawn using a random sampling technique. The age range was from 13-17 years.

\section{Results and Discussion}

Table 1: Overall meaning in Life

\begin{tabular}{|l|l|l|l|l|l|}
\hline Meaning in life & Low & Average & High & Mean & SD \\
\hline Presence & $41(68.3 \%)$ & $19(31.6 \%)$ & - & 15.37 & 4.2 \\
\hline Search & $33(55 \%)$ & $27(45 \%)$ & - & 17.35 & 3.57 \\
\hline
\end{tabular}

The tables 1 gives information about the overall meaning in life along with presence of meaning and search for meaning in life of street children. From the analysis it can be stated that nearly more than half of sample $(68 \%)$ had low presence of meaning in their life while 31.6 percent of them score $d$ average in presence. In search for meaning in life dimension half of sample scored half of the sample scored low and other half average. The results indicate that presence and search for meaning in life of the street children to be very low. This indicates that they don eet feel life has a valued meaning and purpose and they are not actively exploring or searching for meaning in life.

Table 2: Psychological well being

\begin{tabular}{|c|c|c|c|c|c|}
\hline Dimensions & Low & Average & High & Mean & SD \\
\hline $\begin{array}{c}\text { Positive relations } \\
\text { with others }\end{array}$ & $\begin{array}{c}11 \\
(18.3 \%)\end{array}$ & $\begin{array}{c}40 \\
(66.6 \%)\end{array}$ & $9(15 \%)$ & 11.39 & 3.78 \\
\hline Self acceptance & $15(25 \%)$ & $41(68.3 \%)$ & $4(6.6 \%)$ & 13.46 & 2.68 \\
\hline Autonomy & $13(21.6 \%)$ & $39(65 \%)$ & $8(13.3 \%)$ & 12.75 & 1.98 \\
\hline Personal growth & $13(21.6 \%)$ & $36(60 \%)$ & $10(16.6 \%)$ & 12.58 & 3.78 \\
\hline $\begin{array}{c}\text { Environment } \\
\text { mastery }\end{array}$ & $\begin{array}{c}14 \\
(23.3 \%)\end{array}$ & $27(45 \%)$ & $19(31.6 \%)$ & 14.8 & 2.75 \\
\hline Purpose in life & $18(30 \%)$ & $40(66.6 \%)$ & $2(3.3 \%)$ & 11.76 & 4.38 \\
\hline
\end{tabular}

The table 2 indicates the psychological well being of street children. From the results it could be interpreted that in positive relations with other 66 percent of sample scored average while $18 \%$ showed low positive relations with others while $15 \%$ high positive relations. In self acceptance dimension also 68 percent of them had average while 25 percent low self acceptance. Sixty five percent of the 


\section{International Journal of Science and Research (IJSR) \\ ISSN (Online): 2319-7064}

Index Copernicus Value (2015): 78.96 | Impact Factor (2015): 6.391

sample scored average on autonomy dimension while 21 percent showed low autonomy. It was interesting to note from the study that 31 percent of the scored high on environment mastery and 66 percent of them scored average on purpose of life dimension. It could be concluded from the study that in psychological well being dimensions majority were in average category.

Table 3: Correlation of meaning in life and psychological well being

\begin{tabular}{|c|c|c|c|c|c|c|c|}
\hline Dimensions & $\begin{array}{c}\text { Total psychological } \\
\text { well being }\end{array}$ & $\begin{array}{c}\text { Positive relations } \\
\text { with others }\end{array}$ & $\begin{array}{c}\text { Self } \\
\text { acceptance }\end{array}$ & Autonomy & $\begin{array}{c}\text { Personal } \\
\text { growth }\end{array}$ & $\begin{array}{c}\text { Environment } \\
\text { mastery }\end{array}$ & $\begin{array}{c}\text { Purpose in } \\
\text { life }\end{array}$ \\
\hline Presence of meaning & 0.88 & 0.45 & 0.7 & 0.53 & 0.62 & 0.28 & 0.87 \\
\hline Search for meaning & 0.4 & 0.56 & 0.65 & 0.27 & 0.34 & 0.19 & 0.76 \\
\hline Overall meaning & 0.78 & 0.32 & 0.54 & 0.45 & 0.51 & 0.23 & 0.82 \\
\hline
\end{tabular}

Table 3 depicts the relationship between meaning in life and psychological well being. The results show moderate to strong relationship between the variables. From the results a predicative relation between meaning of life and psychological well being can be interpreted. Meaning of life shows a direct positive relation with psychological well being.

\section{Conclusion}

The street children are vulnerable and are generally excluded from main stream society. They lack access to basic necessities of life and frequently discriminated. These conditions of has great impact on psychological well being of these children. The results of study indicate the street children not having a feel of valued meaning and purpose and also they are actively exploring the meaning of life. The psychological well being of these children was also found to be low to average. The correlation depicted a positive relationship between meaning to life and psychological well being. This calls for a holistic intervention approach considering individual children es need including work. The findings suggest that meaning to life and well being are interdependent. Rehabilitative approaches which includes vocational training courses should be planned to improve the well being of these most vulnerable section of the population. being. Journal of Personality and Social Psychology, 57, 1069-1081.

[9] Stephen, J., Fraser, E., \& Marcia, J.E. (1992). Moratorium-achievement (MAMA) cycles in life 38 span identity development: Value orientations and reasoning system correlates. Journal of Adolescence, $15,283-300$

[10] Shek, D. (1992). Meaning in life and psychological well-being: an empirical study using the Chinese version of the purpose in life questionnaire. Journal of Genetic Psychology, 153, 185-190

[11]Zika, S., \& Chamberlain, K. (1987).Relation of hassles and personality to subjective well-being. Journal of Personality and Social Psychology, 53, 155-162.

\section{References}

[1] Ayerst, S. L. (1999) ,Depression and stress in street youth ${ }^{\text {ee }}$ Adolescence 34(135):567-575.

[2] Baumeister, R. F. (1991). Meanings of life. New York: Guilford.

[3] Donald, D., \& Swart-Kruge, J. (1994) „The South African street child: Developmental implications ${ }^{\text {ee }}$, The South African Journal of Psychology 24(4): 169-174.

[4] Erikson, E. (1982). The life cycle completed. New York: Norton.

[5] Ledbetter, M.F., Smith, L.A., \&Vosler-Hunter, W.L. (1991).An evaluation of the research and clinical usefulness of the spiritual well-being scale.Journal of Psychology and Theology, 19, 49- 55.

[6] Lukas, E. (1991). Meaning-centered family therapy. The International Forum for Logotherapy, 14, 67-74.

[7] Recker, G., Peacock, E., \& Wong, P. (1987). Meaning and purpose in life and well-being: A life-span perspective. Journal of Gerontology, 42, 44-49.

[8] Ryff, C. D. (1989). Happiness is every thing, or is it? Explorations on the meaning of psychological well- 